\title{
Thermocalcic Aggregation of Milk Fat Globule Membrane Fragments from Acid Buttermilk Cheese Whey
}

\author{
R. Rombaut ${ }^{1}$ and K. Dewettinck \\ Laboratory of Food Technology and Engineering, Department of Food Safety and Food Quality, Faculty of Bioscience Engineering, \\ Ghent University, Belgium
}

\begin{abstract}
Fragments originating from the milk fat globule membrane (MFGM), which is rich in polar lipids and membrane-specific proteins, are gaining interest for their functional and nutritional properties. Acid buttermilk cheese whey was used as a source for MFGM purification, because its MFGM content is more than 5 times higher than that of standard rennet whey. Because polar lipids are the main constituent of the MFGM and only occur in membranous structures, the polar lipid content was taken as a parameter for the total MFGM fragment content. The process of thermocalcic aggregation was evaluated on its recovery of MFGM fragments in the pellet. This method, originally intended for whey clarification and defatting, is a combination of calcium addition, a $\mathrm{pH}$ increase, and a thermal treatment. The influence of $\mathrm{pH}$ (6.5 to 8$)$, temperature $\left(40\right.$ to $70^{\circ} \mathrm{C}$ ), and calcium concentration ( 0.1 to $0.24 \mathrm{~g} / 100 \mathrm{~g}$ ) on the pellet mass and dry matter (DM) content and on recovery of protein and polar lipids (and thus indirectly on MFGM fragments) was investigated by means of a response surface Box-Behnken orthogonal design. Reduced quadratic models were fit to the experimental data and were found to be highly significant. No outliers were observed. The recovery of MFGM fragments was found to be highly dependent on the $\mathrm{pH}$, and less dependent on temperature and calcium addition. Next to MFGM proteins, whey proteins were also found to be involved in the formation of aggregates. Optimal conditions were found at $55^{\circ} \mathrm{C}, \mathrm{pH} 7.7$, and $0.205 \mathrm{~g}$ of calcium/L of whey. Under these conditions, $91.0 \%$ of the whey polar lipids were recovered in a firm and compact pellet of only $7.86 \%$ of the original whey mass, with a polar lipid concentration of $8.34 \%$ on pellet DM. Washing with water and centrifugation of the pellet was successful because after one washing step, virtually all sugars were removed, whereas $75.9 \%$ of the whey polar lipids could still be
\end{abstract}

Received October 27, 2006.

Accepted February 5, 2007.

${ }^{1}$ Corresponding author: roeland.rombaut@UGent.be recovered. As such, the polar lipid content of the washed pellet increased to $10.70 \%$ on a DM basis. However, a second washing step resulted in serious losses of MFGM material.

Key words: acid buttermilk cheese whey, milk fat globule membrane, thermocalcic aggregation

\section{INTRODUCTION}

Whey, the by-product of cheese and CN manufacturing, is used for making whey protein concentrates and pure isolates, which are applied as emulsifier, stabilizer, and foaming agents. Whey possesses 0.4 to $0.5 \%$ of residual fat, belonging to the sedimentable lipid fraction upon high-speed centrifugation, and consisting of small fat globules, lipoprotein particles, and milk fat globule membrane (MFGM) fragments. This lipid fraction is responsible for whey turbidity and can seriously alter the functionality of whey protein concentrates. It is the main cause of flux decline and fouling during membrane processing of whey. Therefore, prior to ultrafiltration, this lipid fraction should be removed by a whey pretreatment. Several techniques for the clarification of whey have been described. De Wit and De Boer (1977) found that a reduction of the ionic strength through electrodialysis and an adjustment of the $\mathrm{pH}$ to 4.6 induced coagulation of the lipoproteins, which could be separated by decantation. Others used phosphates (Grindstaff and Ahern, 1974), polyphosphates (Melachouris, 1977), a polyanionic agent (Best et al., 1982), a polycationic agent (Grasselli et al., 1995), or a combination of saponins and bile salts (Hwang and Damodaran, 1994) to clarify the whey. Bough and Landes (1976) were the first to apply chitosan (a polyglucosamine polymer that is produced by deacetylation of chitin, the main component of the shell of crustaceae) for whey clarification, and this technique was further examined by Wu et al. (1978), Hwang and Damodaran (1995), and Savant and Torres (2000). However, it was Attebery (1968) who first patented the use of a divalent cation, preferably $\mathrm{Ca}^{2+}$, in combination with a $\mathrm{pH}$ adjustment to 7 to 7.5 and a moderate heat treatment. By this thermocalcic treatment, calcium phosphate is formed, in which MFGM fragments, lipo- 
proteins, and residual fat globules are entrapped. The method was applied to acid whey (Fauquant et al., 1985a) and sweet whey (Fauquant et al., 1985b) and finally adapted to all types of whey (Maubois et al., 1987). The latter method can be considered as the reference. Here, the whey is cooled to $2^{\circ} \mathrm{C}$, the calcium content is adjusted to $1.2 \mathrm{~g} / \mathrm{kg}$, the $\mathrm{pH}$ is raised to $\mathrm{pH} 7.3$ with caustic soda, and the temperature is brought to $50^{\circ} \mathrm{C}$ and maintained for $8 \mathrm{~min}$. As such, a white precipitate is formed, which can be removed by decantation, centrifugation, or tangential filtration. The supernatant is completely transparent and can easily be processed. An indepth investigation of the physicochemical factors of this method was done by Pierre et al. (1992), who found that the initial Ca level and final temperature were the most significant factors, whereas the initial temperature and $\mathrm{pH}$ were insignificant. A modification was suggested by Gésan et al. (1995), who found that the $\mathrm{pH}$ dropped from 7.2 to 6.4 during heating, and proposed to keep the $\mathrm{pH}$ constant while increasing the temperature to $55^{\circ} \mathrm{C}$. This modification resulted in larger aggregates and lower soluble $\mathrm{Ca}$ and phosphate contents of the clarified whey. According to Lehmann and Wasen (1990), this thermocalcic aggregation method has various drawbacks. Because $\mathrm{CaCl}_{2}$ is added before heating, a high precipitation of $\mathrm{Ca}$ and clogging of the heat exchanger can occur. The use of large quantities of $\mathrm{CaCl}_{2}$ can further lead to heavy corrosion of the installation. Therefore, they proposed adding $\mathrm{CaCl}_{2}$ after $\mathrm{pH}$ adjustment and heating.

Although these techniques have been developed for the delipidation and clarification of whey prior to further processing, the corresponding sludge can be of interest because it is enriched in MFGM fragments. These MFGM particles originally surround the fat globules in raw milk, keeping them in emulsion and protecting them from enzymatic attack (Danthine et al., 2000). The MFGM is a true biological bilayer of polar lipids (PL; phospho- and sphingolipids) and membrane-specific proteins. Nowadays, there is growing interest in these MFGM fragments, because some constituents are known to be highly bioactive components that have profound effects on cell metabolism and regulation. In particular, the sphingolipids in dairy products, mainly sphingomyelin and smaller amounts of glucosyl- and lactosylceramide, are gaining attention as evidence of their tumorsuppressing (Schmelz et al., 1996; Schmelz, 2004) and cholesterol uptake-lowering effects (Eckhardt et al., 2002; Noh and Koo, 2004) has accumulated. Next to sphingolipids, the MFGM proteins are also believed to exert health-promoting properties. Peptides of these proteins can positively interfere in breast and colon cancer, multiple sclerosis, and hypercholesterolemia (Spitsberg, 2005). In addition to their nutritional properties, MFGM fragments also possess good emulsifying capacities, which originate from the amphiphilic nature of the membrane components (Kanno et al., 1991; Roesch et al., 2004). As such, these isolates could be applied as emulsifiers with health-improving properties in a whole range of food products (e.g., mayonnaises, margarines, recombined butter, instant milk powder) as well as in cosmetics and pharmaceuticals.

The purpose of this study was to investigate the influence of thermocalcic aggregation temperature, $\mathrm{pH}$, and Ca content on the recovery of MFGM fragments in the pellet after clarification. Acid buttermilk cheese whey was chosen as a whey source for its high content of MFGM fragments. The MFGM fragments were further concentrated by washing the pellet. Milk fat globule membrane fragments as such are not measurable; therefore, the concentration of PL, their main constituents, are taken as a parameter for MFGM fragment concentration.

\section{MATERIALS AND METHODS}

\section{Materials}

The whey ( $\mathrm{pH} 4.62)$ used for coagulation experiments was obtained by acidification of buttermilk by starter culture addition followed by a centrifugal separation into a fresh cheese of the Quarg type and acid whey (Boone, 2003). It originated from one batch and was kindly provided by Büllinger Butterei (Büllingen, Belgium). The whey was frozen at $-25^{\circ} \mathrm{C}$ until processing. All reagents used during processing and analysis were of analytical grade. Chloroform, methanol, triethylamine, and formic acid, used as the mobile phase for HPLC analysis of PL, were of HPLC grade. A milk PL standard was supplied by Spectral Services GmbH (Köln, Germany).

\section{Analysis}

DM, Ash, Ca, Protein, Lipids, Reducing Sugars, and $\boldsymbol{P L}$. Dry matter analyses were performed by gravimetric difference after heating (IDF, 2004). Ash content was determined by gravimetric difference after ashing following AOAC method 945.46 (AOAC, 2002). Calcium content of the acid buttermilk whey was determined by flame atomic absorption spectrometry (IDF, 1992). Total lipid content was measured gravimetrically after evaporation of the extraction solvent using the Röse-Gottlieb extraction method (IDF, 1986). The protein content was obtained using the Kjeldahl nitrogen determination method (IDF, 1993), using 6.38 as the protein conversion factor. Sugar content was determined by measuring the amount of reducing sugars (Luff-Schoorl method; Acker, 1969). Polar lipid extraction and analysis by HPLC (ThermoFinnigan Surveyor, Thermo Corp., Brussels, Belgium) coupled to an evaporative light-scattering de- 
tector (ELSD 2000, Alltech Inc., Lokeren, Belgium) were performed as described elsewhere (Rombaut et al., 2005). All values are expressed as the mass percentage, unless stated otherwise. All analyses were performed in duplicate.

Protein Profiling by SDS-PAGE. All reagents and precast gels were purchased from Invitrogen (Merelbeke, Belgium). The samples were prepared following the manufacturer's protocol. NuPAGE LDS sample buffer $(250 \mu \mathrm{L})$ and NuPAGE reducing agent $(100 \mu \mathrm{L})$ were added to $650 \mu \mathrm{L}$ of sample. The samples were vortexed and heated at $70^{\circ} \mathrm{C}$ for $10 \mathrm{~min}$ in a hot water bath. Ten microliters of each sample was loaded onto a NuPAGE bis-tris 4 to $12 \%$ polyacrylamide gel (dimension: $10 \times 10$ $\times 0.15 \mathrm{~cm}$ ). 3- $N$-Morpholinopropanesulfonic acid buffer was used as running buffer. Separation was performed in $55 \mathrm{~min}$ at $200 \mathrm{~V}$ and an initial current of $125 \mathrm{~mA} /$ gel. After separation, the gel was washed 3 times with deionized water and stained for 60 min with SimplyBlue SafeStain (Coomassie blue). The gel was destained for $60 \mathrm{~min}$ in deionized water and further destained overnight in $100 \mathrm{~mL}$ of a $3.3 \% \mathrm{NaCl}$ solution to increase staining intensity. Scanning of the wet gel was done with a high-resolution transmission scanner (UMAX Powerlook III, UMAX, Taipei, Taiwan). Gels were analyzed with ImageMaster TotalLab software (Amersham Biosciences, Roosendaal, the Netherlands).

The MFGM protein standard was purified from fresh raw milk, which was obtained from a local farmer. Ten liters of milk was decreamed at $42^{\circ} \mathrm{C}$ with a small continuous separator (Westfalia Separator, Oelde, Germany) at $9,500 \times \mathrm{g}$ and washed 3 times with $9 \mathrm{~L}$ of a $1.5 \mathrm{~g} / \mathrm{L}$ $\mathrm{KCl}$ solution. The washed cream was churned with a household beater during $10 \mathrm{~min}$. The butter obtained was melted at $60^{\circ} \mathrm{C}$ and an equal quantity of distilled water was added. The resulting slurry was centrifuged in a batch laboratory centrifuge (Martin Christ Osterode, Harz, Germany) at $2,400 \times g$ for $5 \mathrm{~min}$ at $60^{\circ} \mathrm{C}$ and the butter serum was collected. Butter serum and buttermilk were pooled and freeze-dried. To remove the lipids, the powder was washed with chloroform, filtered through a paper filter, and allowed to dry. The purified MFGM protein powder was stored at $-32^{\circ} \mathrm{C}$. Classification of MFGM proteins was done according to Mather (2000).

\section{Experimental Design of Thermocalcic Aggregation}

The effect of temperature, $\mathrm{pH}$, and Ca concentration on the recovery of MFGM fragments in the pellet during thermocalcic aggregation was determined by means of an experimental design (response surface Box-Behnken orthogonal design). The yield and DM of the pellet and the recovery of PL and proteins in the pellet were taken as response variables, because the purpose of this investigation was to recover a maximum of PL in a firm pellet, with a minimum of other compounds, especially proteins. The factors of the design were constrained between 40 and $70^{\circ} \mathrm{C}$, a pH between 6.5 and 8 , and a Ca concentration between 0.10 and $0.24 \mathrm{~g}$ of $\mathrm{Ca} / 100 \mathrm{~g}$ of whey. Because the $\mathrm{Ca}$ content of the original acid buttermilk whey amounted to $0.080 \pm 0.002 \mathrm{~g} / 100 \mathrm{~g}$, between 0.02 and $0.16 \mathrm{~g}$ of $\mathrm{Ca} / 100 \mathrm{~g}$ of whey was added. Seventeen design points (coagulation experiments) were defined, of which 12 points were taken at different combinations of factorial levels (coded levels $-1,0$, and +1 ) and 5 center points, to determine the pure experimental error. These experimental combinations are given in Table 1 . All coagulation experiments were performed using $2 \mathrm{~L}$ of acid buttermilk whey following the protocol of Lehmann and Wasen (1990), but at the temperature, $\mathrm{pH}$, and Ca addition specified by the experimental design. After clarification, the pellet was separated by centrifugation at $40^{\circ} \mathrm{C}$ with a batch lab centrifuge (Martin Christ Osterode, Harz, Germany) at 2,400 $\times$ g. The supernatant and pellet were separated and stored at $-32^{\circ} \mathrm{C}$ until analysis. All tests were carried out in a randomized order to minimize the time effect.

\section{Graphics and Statistics}

Graphics were generated with SigmaPlot 6.0 (SPSS, Chicago, IL). Statistics and experimental design were performed with SPSS 12.0 (SPSS, Chicago, IL) and Design Expert 5.0 (Stat-Ease Inc., Minneapolis, MN).

\section{RESULTS}

\section{Effect of pH, Temperature, and Ca Addition}

Whey Composition. The PL content of the acid buttermilk whey was $110 \pm 1 \mathrm{mg} / 100 \mathrm{~g}$, about 5 times higher than standard rennet whey (Rombaut et al., 2007), which makes this fraction highly suitable as a source of MFGM material. Major PL were phosphatidylethanolamine $(29.5 \pm 4.2 \mathrm{~g} / 100 \mathrm{~g}$ of PL), phosphatidylcholine (24.7 \pm $1.1 \mathrm{~g} / 100 \mathrm{~g}$ of PL), and sphingomyelin $(21.5 \pm 2.3 \mathrm{~g} / 100$ $\mathrm{g}$ of PL). Minor PL were phosphatidylinositol (11.7 \pm 3.7 $\mathrm{g} / 100 \mathrm{~g}$ of PL), phosphatidylserine $(5.4 \pm 0.8 \mathrm{~g} / 100 \mathrm{~g}$ of PL), lactosylceramide (5.3 $\pm 0.3 \mathrm{~g} / 100 \mathrm{~g}$ of $\mathrm{PL})$, and glucosylceramide $(1.9 \pm 0.5 \mathrm{~g} / 100 \mathrm{~g}$ of PL). The total sphingolipid content accounted for $28.7 \pm 2.4 \mathrm{~g} / 100 \mathrm{~g}$ of PL. The Ca content of the acid buttermilk whey amounted to $0.080 \pm 0.002 \mathrm{~g} / 100 \mathrm{~g}$.

Experimental Design. A quadratic model was fit to the data. Nonsignificant $(P>0.1)$ model coefficients were eliminated by a stepwise addition algorithm, resulting in a reduced quadratic model. However, the hierarchy of the model was maintained, meaning if a quadratic 
Table 1. Response surface Box-Behnken orthogonal experimental design ${ }^{1}$

\begin{tabular}{|c|c|c|c|c|c|c|c|c|c|c|}
\hline \multirow{2}{*}{\multicolumn{3}{|c|}{ Design factors }} & \multicolumn{8}{|c|}{ Response variables } \\
\hline & & & \multicolumn{2}{|c|}{$\begin{array}{l}\text { Pellet mass } \\
\text { (g/100 g } \\
\text { of whey) }\end{array}$} & \multicolumn{2}{|c|}{$\begin{array}{c}\text { Pellet DM } \\
(\mathrm{g} / 100 \mathrm{~g})\end{array}$} & \multicolumn{2}{|c|}{$\begin{array}{l}\text { Polar lipids } \\
\text { recovery in pellet } \\
\text { (\% of total whey } \\
\text { polar lipids) }\end{array}$} & \multicolumn{2}{|c|}{$\begin{array}{c}\text { Protein recovery } \\
\text { (\% of total } \\
\text { whey protein) }\end{array}$} \\
\hline $\mathrm{T}^{2}\left({ }^{\circ} \mathrm{C}\right)$ & $\mathrm{pH}$ & of whey) & $\mathrm{AV}$ & PV & $\mathrm{AV}$ & PV & $\mathrm{AV}$ & PV & $\mathrm{AV}$ & PV \\
\hline 40 & 6.5 & 0.17 & 2.6 & 2.8 & 14.4 & 14.7 & 32.4 & 33.9 & 15.0 & 18.1 \\
\hline 70 & 6.5 & 0.17 & 3.3 & 3.1 & 16.2 & 16.4 & 35.9 & 34.9 & 23.7 & 25.8 \\
\hline 40 & 8 & 0.17 & 8.9 & 9.1 & 11.1 & 10.9 & 76.1 & 81.2 & 30.1 & 29.2 \\
\hline 70 & 8 & 0.17 & 6.9 & 6.7 & 17.0 & 16.7 & 86.7 & 82.2 & 48.3 & 46.5 \\
\hline 40 & 7.25 & 0.1 & 8.0 & 7.7 & 11.3 & 11.4 & 79.3 & 74.7 & 27.1 & 27.9 \\
\hline 70 & 7.25 & 0.1 & 6.5 & 6.6 & 15.4 & 15.2 & 72.6 & 75.7 & 40.1 & 40.4 \\
\hline 40 & 7.25 & 0.24 & 8.1 & 7.9 & 13.3 & 13.2 & 82.8 & 80.7 & 33.5 & 32.9 \\
\hline 70 & 7.25 & 0.24 & 6.4 & 6.8 & 16.8 & 17.0 & 79.3 & 81.7 & 43.6 & 45.4 \\
\hline 55 & 6.5 & 0.1 & 3.1 & 3.3 & 14.4 & 14.0 & 40.0 & 38.2 & 20.1 & 15.8 \\
\hline 55 & 8 & 0.1 & 8.4 & 8.3 & 11.8 & 12.3 & 83.4 & 85.6 & 28.6 & 31.7 \\
\hline 55 & 6.5 & 0.24 & 3.8 & 3.5 & 15.9 & 15.8 & 42.8 & 44.2 & 21.8 & 20.9 \\
\hline 55 & 8 & 0.24 & 8.5 & 8.5 & 14.0 & 14.1 & 94.3 & 91.6 & 37.1 & 36.7 \\
\hline 55 & 7.25 & 0.17 & 6.8 & 6.8 & 16.0 & 16.1 & 85.6 & 85.0 & 39.8 & 40.3 \\
\hline 55 & 7.25 & 0.17 & 6.6 & 6.8 & 16.3 & 16.1 & 82.1 & 85.0 & 41.4 & 40.3 \\
\hline 55 & 7.25 & 0.17 & 6.7 & 6.8 & 16.3 & 16.1 & 81.2 & 85.0 & 39.6 & 40.3 \\
\hline 55 & 7.25 & 0.17 & 6.3 & 6.8 & 16.6 & 16.1 & 81.4 & 85.0 & 39.7 & 40.3 \\
\hline 55 & 7.25 & 0.17 & 7.5 & 6.8 & 15.4 & 16.1 & 93.7 & 85.0 & 43.3 & 40.3 \\
\hline
\end{tabular}

term was found significant, the linear term was also included, regardless of its significance. Table 1 gives the experimental design as well as the measured values and the predicted values by the fitted reduced quadratic models. In Table 2, the ANOVA sum of squares, fitted regression coefficients, and $t$-tests are given for the reduced quadratic models for each response variable. The predicted residual sum of squares was calculated by recalculating the model coefficients using the data points minus one. This new model was then used to estimate the value for the nonincluded point. This was done for each point, and the difference between each predicted and actual value was squared and summed, giving the predicted residual sum of squares. The predicted determination coefficient $\left(\mathrm{R}^{2}\right)$ is based on the latter and gives information about how well the model fits each point in the design, and whether the model is prone to small variations of one of the data points. The value should be close to one. All models were found to be highly significant ( $P$ $<0.0001$ ). Lack of fit tests, in which the pure error was

Table 2. Statistical parameters of the reduced quadratic models fitted to the experimental data obtained upon thermocalcic aggregation of acid buttermilk whey as a function of temperature, $\mathrm{pH}$, and $\mathrm{Ca}$ concentration

\begin{tabular}{|c|c|c|c|c|}
\hline \multirow[b]{2}{*}{ ANOVA terms } & \multicolumn{4}{|c|}{ Response variables } \\
\hline & $\begin{array}{c}\text { Pellet mass } \\
\text { (g/100 g of whey) }\end{array}$ & $\begin{array}{l}\text { Pellet DM } \\
(\mathrm{g} / 100 \mathrm{~g})\end{array}$ & $\begin{array}{l}\text { Polar lipid } \\
\text { recovery in pellet } \\
\text { (\% of total } \\
\text { whey polar lipids) }\end{array}$ & $\begin{array}{c}\text { Protein recovery } \\
\text { in pellet } \\
\text { (\% of total } \\
\text { whey protein) }\end{array}$ \\
\hline \multicolumn{5}{|l|}{ Sum of squares } \\
\hline Model & 62.08 & 58.05 & $6,547.09$ & $1,419.29$ \\
\hline Residual & 1.51 & 1.45 & 219.12 & 63.44 \\
\hline Lack of fit & 0.67 & 0.61 & 107.85 & 52.94 \\
\hline Pure error & 0.84 & 0.84 & 111.27 & 10.51 \\
\hline Corrected total & 63.59 & 59.50 & $6,766.21$ & $1,482.74$ \\
\hline Predicted residual & 4.94 & 6.15 & 493.41 & 305.03 \\
\hline \multicolumn{5}{|c|}{ Significance ( $P$-value $)$} \\
\hline Model & $<0.0001$ & $<0.0001$ & $<0.0001$ & $<0.0001$ \\
\hline Lack of fit & 0.7633 & 0.7164 & 0.7677 & 0.1305 \\
\hline \multicolumn{5}{|c|}{ Determination coefficients } \\
\hline $\mathrm{R}^{2}$ & 0.9762 & 0.9756 & 0.9676 & 0.9572 \\
\hline Predicted $\mathrm{R}^{2}$ & 0.9223 & 0.8967 & 0.9271 & 0.7943 \\
\hline
\end{tabular}


Table 3. Final equation terms and significance of the quadratic model coefficients for prediction of parameters within the design limits of the model [temperature (T) 40 to $70^{\circ} \mathrm{C}$, pH 6.5 to 8 , and Ca concentration 0.1 to $0.24 \mathrm{~g} / 100 \mathrm{~g}$ of whey] ${ }^{1}$

\begin{tabular}{|c|c|c|c|c|c|c|c|c|}
\hline \multirow[b]{2}{*}{$\begin{array}{l}\text { Model } \\
\text { coefficient }\end{array}$} & \multicolumn{4}{|c|}{ Significance $(P$-value $)$} & \multicolumn{4}{|c|}{ Final equation terms } \\
\hline & $\begin{array}{c}\text { Pellet } \\
\text { mass } \\
\text { (g/100 g } \\
\text { of whey) }\end{array}$ & $\begin{array}{c}\text { Pellet DM } \\
(\mathrm{g} / 100 \mathrm{~g})\end{array}$ & $\begin{array}{l}\text { Polar lipid } \\
\text { recovery in } \\
\text { pellet (\% of } \\
\text { total whey } \\
\text { polar lipids) }\end{array}$ & $\begin{array}{c}\text { Protein } \\
\text { recovery } \\
\text { in pellet } \\
(\% \text { of total } \\
\text { whey protein) }\end{array}$ & $\begin{array}{l}\text { Pellet } \\
\text { mass } \\
\text { (g/100 g } \\
\text { of whey) }\end{array}$ & $\begin{array}{c}\text { Pellet DM } \\
(\mathrm{g} / 100 \mathrm{~g})\end{array}$ & $\begin{array}{l}\text { Polar lipid } \\
\text { recovery in } \\
\text { pellet (\% of } \\
\text { total whey } \\
\text { polar lipids) }\end{array}$ & $\begin{array}{c}\text { Protein } \\
\text { recovery } \\
\text { in pellet } \\
\text { (\% of total } \\
\text { whey protein) }\end{array}$ \\
\hline Intercept & & & & & -162.48 & -38.74 & $-2,128.46$ & -972.06 \\
\hline $\mathrm{T}$ & 0.0022 & $<0.0001$ & 0.7606 & $<0.0001$ & 0.39 & -0.24 & 3.37 & -1.13 \\
\hline $\mathrm{T}^{2}$ & NS & 0.0112 & 0.0094 & NS & 0 & -0.0028 & -0.030 & 0 \\
\hline $\mathrm{pH}^{2}$ & $<0.0001$ & 0.0027 & $<0.0001$ & $<0.0001$ & -2.40 & -1.43 & -35.84 & -18.46 \\
\hline $\mathrm{Ca}^{2}$ & 0.0306 & 0.0001 & NS & 0.0149 & 97.10 & -257.95 & 0 & -734.38 \\
\hline $\mathrm{T} \times \mathrm{pH}$ & 0.0064 & 0.0006 & NS & 0.0863 & -0.059 & 0.092 & 0 & 0.21 \\
\hline $\mathrm{T} \times \mathrm{Ca}$ & NS & NS & NS & NS & 0 & 0 & 0 & 0 \\
\hline $\mathrm{T} \times \mathrm{pH}$ & NS & NS & NS & NS & 0 & 0 & 0 & 0 \\
\hline
\end{tabular}

${ }^{1}$ Some nonsignificant terms were included in the model to respect the model hierarchy.

compared with the rest of the residual error (lack of fit error) were found to be insignificant. No significant outliers were observed. The determination coefficient and predicted determination coefficient were sufficiently high. Of all these parameters, we concluded that the reduced quadratic models were well suited for trend analysis and parameter estimation within the constraints of the design factors. Table 3 gives the significance of each model coefficient and the final model equation terms. The latter can be used for response prediction.

Pellet Yield and DM. The effects of $\mathrm{pH}$ and temperature on pellet mass and pellet DM at a Ca concentration of $0.205 \mathrm{~g} / 100 \mathrm{~g}$ of whey are presented in Figure 1A and 1B, respectively. From Table 3 and Figure 1A and 1B, it is clear that the $\mathrm{pH}$ had a profound effect on the pellet mass, whereas the temperature had the highest effect on pellet DM. Upon an increase in $\mathrm{pH}$, the pellet yield increased but the DM content of the pellet decreased, especially at low temperatures. There was clearly a significant interaction effect between temperature and $\mathrm{pH}$; pellet yield was not affected by the temperature at a low $\mathrm{pH}$, whereas at a high $\mathrm{pH}$, higher temperatures resulted in a decrease of the pellet mass. Similarly, the pellet $\mathrm{DM}$ content was affected more at high $\mathrm{pH}$ values than at low $\mathrm{pH}$ values. Here, a higher temperature clearly increased the DM content of the pellet. This could be observed because at high temperatures, a very firm, compact pellet was obtained, which was easy to separate. Thus, the combination of a high $\mathrm{pH}$ and high temperature resulted in a firm pellet with considerable mass. The effect of $\mathrm{Ca}$ addition was almost negligible regarding pellet yield, but provoked an increase in DM until a maximum was reached at approximately $0.205 \mathrm{~g}$ of Ca/ $100 \mathrm{~g}$ of whey (data not shown).
PL Recovery. Polar lipids were quite concentrated in the pellet. Recoveries varied from 32.4 to $94.3 \%$ of total whey PL. Figure 1C presents the effect of temperature and $\mathrm{pH}$ on $\mathrm{PL}$ recovery in the pellet at a Ca concentration of $0.205 \mathrm{~g} / 100 \mathrm{~g}$ of whey. The $\mathrm{pH}$ has a profound effect on PL recovery, because at low $\mathrm{pH}$, recoveries of less than $40 \%$ were observed, whereas at $\mathrm{pH}$ above 7.5 , more than $90 \%$ of the whey PL were recovered in the pellet. An optimum was observed at $\mathrm{pH}$ 7.7. The effect of temperature was only moderate, with an optimum around $55^{\circ} \mathrm{C}$. There were no significant interaction effects between temperature and Ca content or $\mathrm{pH}$, so this optimal temperature value was independent of variations in $\mathrm{pH}$ or Ca content. The effect of the latter was found to be linear and very small, with slightly increasing values of PL recovery upon $\mathrm{Ca}$ addition. For example, at these conditions ( $\left.\mathrm{pH} 7.7,55^{\circ} \mathrm{C}\right)$, an increase in the Ca concentration from 0.10 to $0.24 \mathrm{~g} / 100 \mathrm{~g}$ of whey would result in a PL recovery increase of only 5\% (data not shown). Results of the presence of MFGM proteins in the supernatants were very similar to those for PL recovery, with a minimum of MFGM proteins in the supernatant at a similar $\mathrm{pH}$ and temperature combination as the optimum for PL recovery (results not shown). This was expected, because nearly all dairy PL are situated in the MFGM (Danthine et al., 2000) and are coprecipitated with MFGM proteins as MFGM fragments.

Protein Recovery. Recovery of proteins in the pellet (whey proteins, MFGM proteins, and peptides) as a function of temperature and $\mathrm{pH}$ (Figure 1D) differed from PL recovery (Figure 1C). Values ranged from 15.0 to $48.3 \%$ of total proteins. In contrast to PL recovery, a highly significant linear effect of temperature was observed. The change in protein recovery upon increasing the $\mathrm{pH}$ could be attributed to MFGM proteins that were 

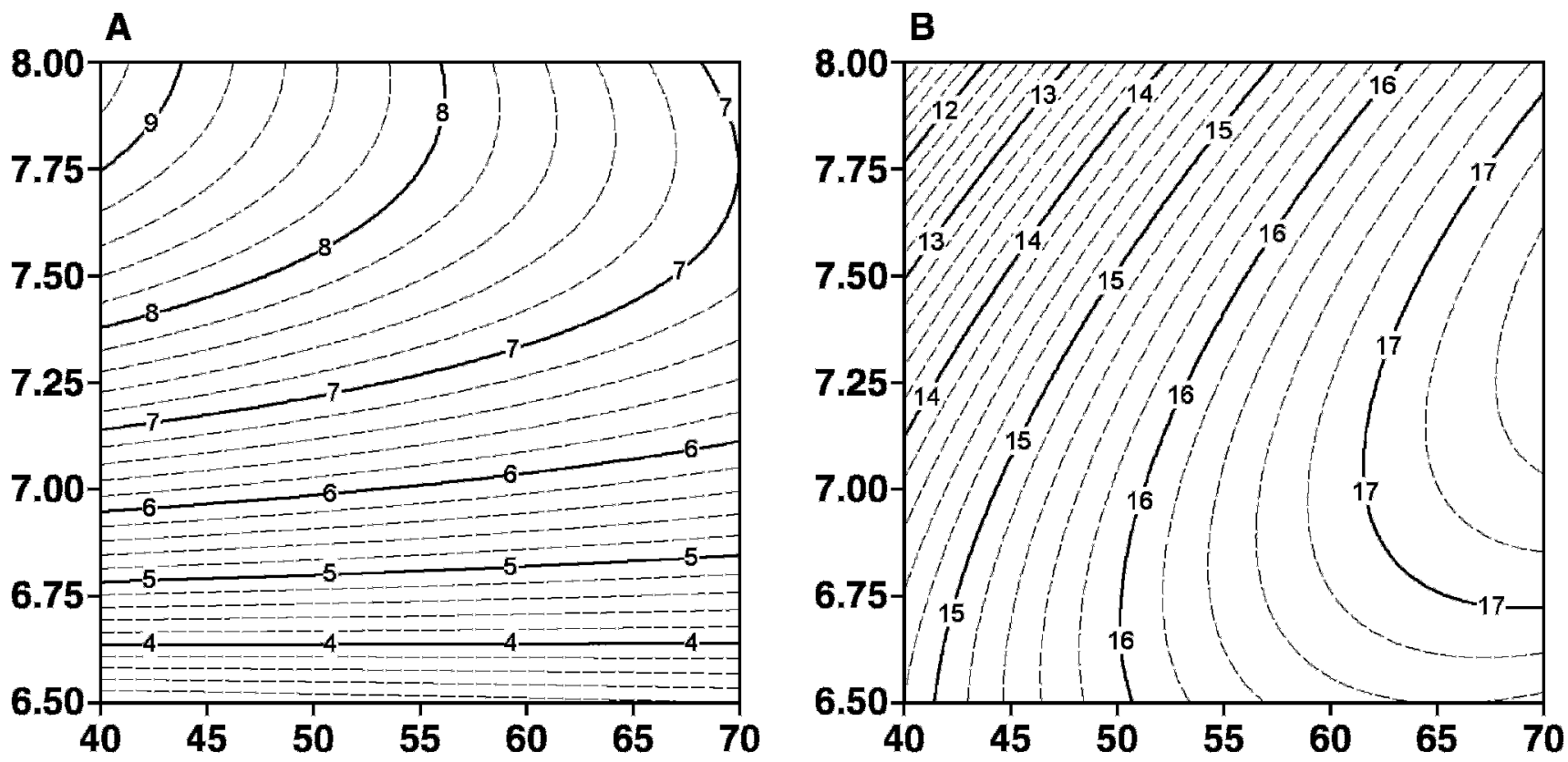

$\frac{I}{2}$
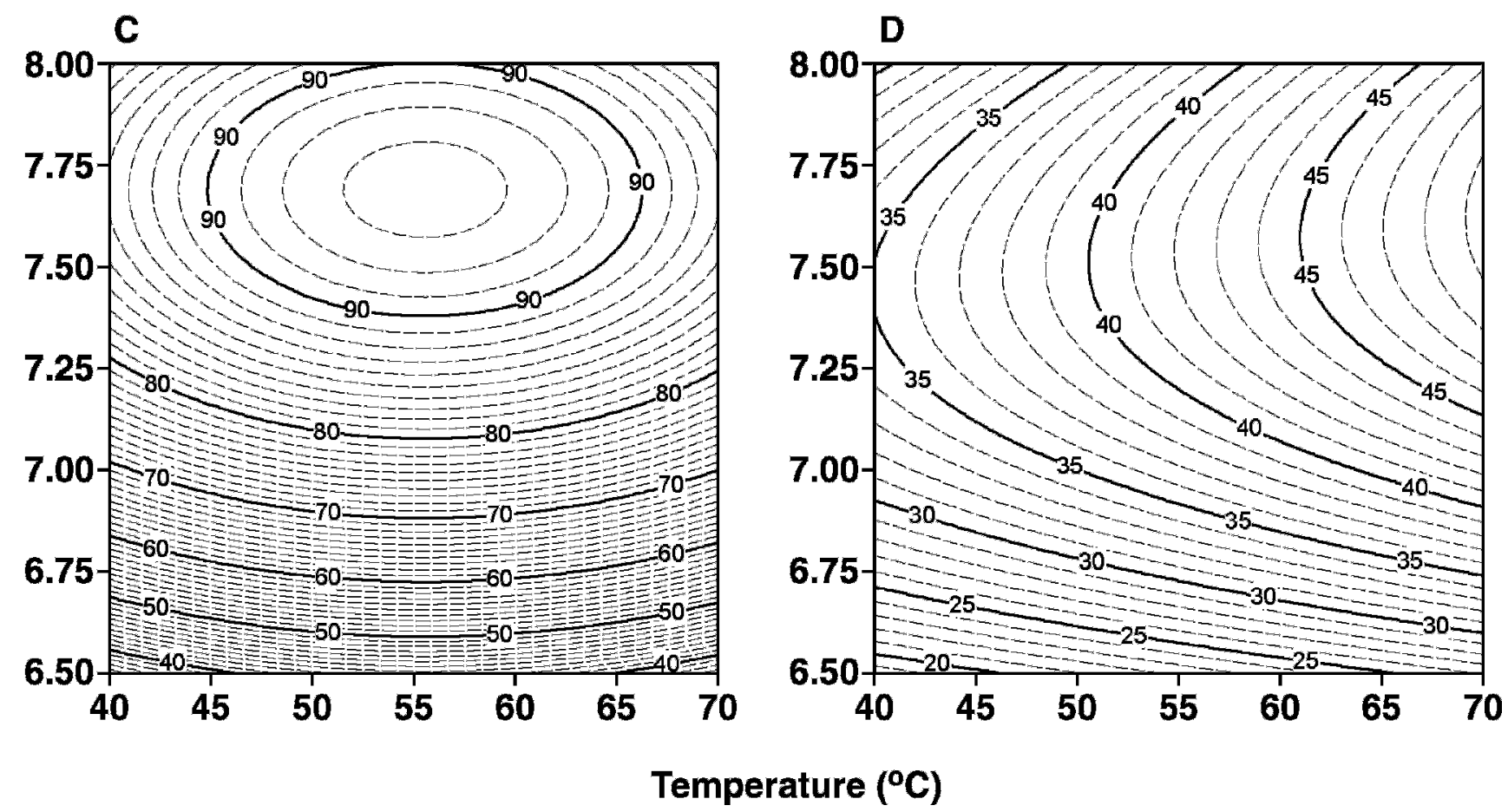

Figure 1. Response variables as a function of temperature and $\mathrm{pH}$ at a Ca concentration of $0.205 \mathrm{~g} / 100 \mathrm{~g}$ of whey. A) Mass of pellet (g/ $100 \mathrm{~g}$ of whey); B) DM content of the pellet ( $\mathrm{g} / 100 \mathrm{~g}$ of pellet); C) recovery (\%) of whey polar lipids in the pellet; D) recovery (\%) of proteins from the whey in the pellet.

precipitated; a similar $\mathrm{pH}$ value for maximum recovery of PL is shown in Figure 1C. However, the increase in protein recovery upon an increase in temperature must be attributed to the precipitation of proteins other than MFGM proteins, because, as shown in Figure 1C, upon a temperature increase, no similar increase in PL recovery was observed. As such, the increase in DM (Figure 1B) upon a rise in temperature was partially attributed to protein precipitation. Here, the influence of $\mathrm{Ca}$ addition led to an increase toward a maximum at around 0.205 


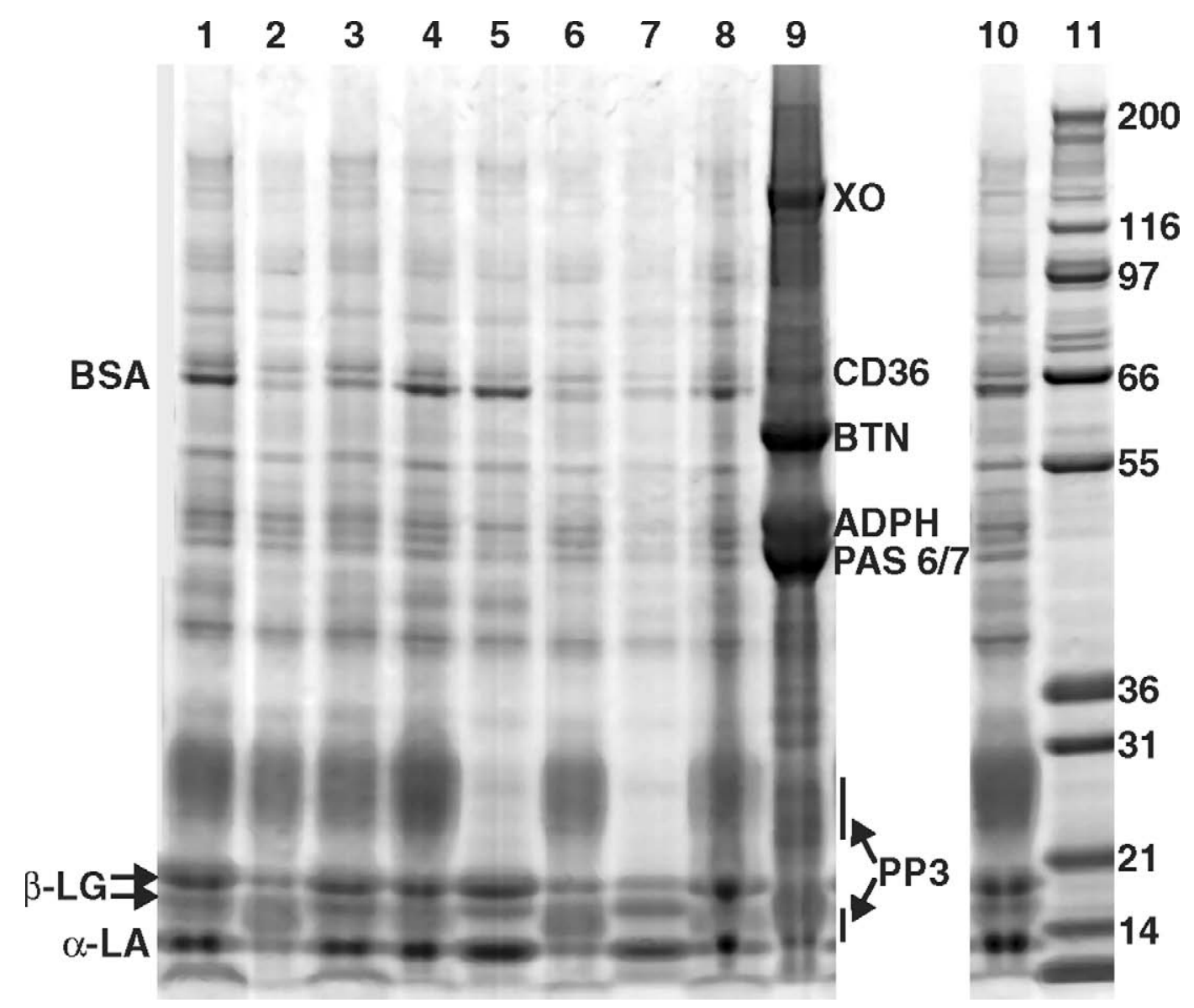

Figure 2. Sodium dodecyl sulfate-PAGE of acid buttermilk cheese whey fractions, after aggregation and separation. Lanes 1 and 2 : supernatant and pellet $\left(40^{\circ} \mathrm{C}, \mathrm{pH} 6.5\right.$, and $0.17 \mathrm{~g}$ of $\mathrm{Ca} / 100 \mathrm{~g}$ of whey); lanes 3 and 4: supernatant and pellet $\left(70^{\circ} \mathrm{C}\right.$, $\mathrm{pH} 6.5$, and $0.17 \mathrm{~g}$ of $\mathrm{Ca} / 100 \mathrm{~g}$ of whey); lanes 5 and 6 : supernatant and pellet $\left(40^{\circ} \mathrm{C}, \mathrm{pH} 8\right.$, and $0.17 \mathrm{~g}$ of $\mathrm{Ca} / 100 \mathrm{~g}$ of whey); lanes 7 and 8: supernatant and pellet $\left(70^{\circ} \mathrm{C}, \mathrm{pH} 8\right.$, and $0.17 \mathrm{~g}$ of $\mathrm{Ca} / 100 \mathrm{~g}$ of whey); lane 9: milk fat globule membrane (MFGM)-protein standard; lane 10: acid buttermilk whey; lane 11: molecular whey standard (kDa). Observed MFGM proteins are xanthine oxidase (XO) adipophilin (ADPH), cluster of differentiation 36 (CD36), periodic acid Schiff 6/7 (PAS 6/7), and proteose peptone 3 fraction 1 and 2 (PP3) and are indicated in the middle. Observed whey proteins are BSA, $\alpha$-LA, and $\beta$-LG genetic variants A and B and are indicated at the left. Butyrophilin (BTN), one of the main MFGM proteins, was not observed.

$\mathrm{g}$ of $\mathrm{Ca} / 100 \mathrm{~g}$ of whey, which is the same value as obtained for the DM content of the pellet upon a change of variables (results not shown).

SDS-PAGE. Figure 2 gives the SDS-PAGE profile of the acid buttermilk cheese whey and some supernatants and pellets. Upon comparison of the whey (lane 10) with the purified MFGM fraction (lane 9), MFGM proteins (e.g., CD36, adipophilin, and periodic acid/Schiff 6/7) could be distinguished. A major and a minor fraction of proteose peptone 3 (PP3) with estimated molecular weights of 25 and $16 \mathrm{kDa}$ were also observed. Although still open to debate, this fraction is considered as part of the MFGM protein fraction (Nejjar et al., 1990; Sorensen et al., 1997). Major whey proteins such as BSA, $\beta$ LG variants A and B (Mailliart and Ribadeau-Dumas, 1988; Ebeler et al., 1990), and $\alpha$-LA could clearly be distinguished. Caseins, which had an observed molecu- lar weight of between 28 and $35 \mathrm{kDa}$, were not detected in the whey. The latter molecular weights were somewhat overestimated because of the abnormal electrophoretic behavior of CN (Basch et al., 1985). These SDSPAGE results should only be interpreted qualitatively and for comparison of the different fractions, because the intensity of coloration of proteins was highly dependent on the type of protein.

The effect of the $\mathrm{pH}$ was noticeable when comparing the supernatants at $\mathrm{pH} 6.5$ (lanes 1 and 3 ) with those at high $\mathrm{pH}$ (lanes 5 and 7). In the latter case, clearly fewer MFGM proteins were present. Both PP3 fractions were virtually removed. The effect of temperature could be observed when comparing the pellets at $40^{\circ} \mathrm{C}$ (lanes 2 and 6) with those at $70^{\circ} \mathrm{C}$ (lanes 4 with 8 ). At $70^{\circ} \mathrm{C}$, clearly more whey proteins were denatured and recovered in the pellet. The temperature effect on MFGM 
Table 4. Composition ( $\mathrm{g} / 100 \mathrm{~g}$ ) of whey, pellets, and supernatants after aggregation and washing of the pellet

\begin{tabular}{|c|c|c|c|c|c|c|c|}
\hline Item & $\mathrm{DM}$ & Ash & Protein & Sugars & Lipids & Polar lipids & Polar lipids/DM \\
\hline Original & $15.80 \pm 0.22^{\mathrm{a}}$ & $4.35 \pm 0.06^{\mathrm{a}}$ & $2.72 \pm 0.05^{\mathrm{a}}$ & $5.05 \pm 0.03^{\mathrm{a}}$ & $3.81 \pm 0.04^{\mathrm{ab}}$ & $1.32 \pm 0.05^{\mathrm{a}}$ & $8.34 \pm 0.35^{\mathrm{a}}$ \\
\hline Wash 2 & $11.68 \pm 0.21^{b}$ & $4.74 \pm 0.33^{\mathrm{a}}$ & $2.71 \pm 0.03^{\mathrm{a}}$ & $<0.01^{\mathrm{b}}$ & $3.74 \pm 0.09^{b}$ & $1.31 \pm 0.09^{\mathrm{a}}$ & $11.18 \pm 0.76^{\mathrm{b}}$ \\
\hline \multicolumn{8}{|l|}{ Supernatants } \\
\hline Original & $5.48 \pm 0.09^{\mathrm{a}}$ & $0.95 \pm 0.01^{\mathrm{a}}$ & $0.28 \pm 0.01^{\mathrm{a}}$ & $3.52 \pm 0.07^{\mathrm{a}}$ & $0.04 \pm 0.00^{\mathrm{a}}$ & $<0.01^{\mathrm{a}}$ & $<0.18^{\mathrm{a}}$ \\
\hline
\end{tabular}

${ }^{\mathrm{a}-\mathrm{c}}$ Means of pellets and supernatants within a column not sharing a common superscript differ at the 0.05 significance level.

proteins was similar, but was less pronounced than the effect on whey proteins. When the supernatants were compared (lane 1 with 3 , and lane 5 with 7), fewer MFGM proteins remained in the supernatant at increased temperatures. Here, the interaction effect with $\mathrm{pH}$ was visible, because the temperature effect was more pronounced at $\mathrm{pH} 8$ than at $\mathrm{pH}$ 6.5. As such, a complete removal of the MFGM proteins from the supernatant also implied a higher precipitation of whey proteins.

\section{Washing of the Pellet}

In a next step, the pellet was washed to remove lactose and other soluble components to increase the PL content on DM. This was done at $\mathrm{pH} 7.7,55^{\circ} \mathrm{C}$, and at a $\mathrm{Ca}$ concentration of $0.205 \mathrm{~g} / 100 \mathrm{~g}$. The supernatant and pellet were separated, and the latter was resuspended in an amount of distilled water equal to the mass of the removed supernatant. Because the $\mathrm{pH}$ decreased by about one unit during resuspension, it was readjusted to 7.7 with $\mathrm{NaOH}(1 N)$. The suspension was then centrifuged into a pellet and a washing supernatant. The washing process was repeated a second time. The conditions applied resulted in a high PL recovery in the pellet $(>90 \%)$ and ensured a high DM content $(>15 \%)$, which was essential for further washing of the pellet.

Table 4 gives the composition of the whey, pellets, and supernatants, and Table 5 gives the pellet recovery after aggregation and washing of the pellet. According to the models given in Table 3, under the applied conditions, $93.5 \pm 4.9 \%$ of the whey PL would be recovered in a pellet of only $8.0 \pm 0.4 \%$ of the original whey mass. The $\mathrm{DM}$ of the pellet and the protein recovery would be $15.4 \pm$ $0.4 \mathrm{~g} / 100 \mathrm{~g}$ and $41.6 \pm 2.7 \%$, respectively. These predicted values correspond highly with the experimental values of the unwashed pellet given in Tables 4 and 5, demonstrating the correctness of the models.

The experimental conditions applied yielded more pellet and PL than the original method of Lehmann and Wasen. However, this was also the case for DM, ash, protein, and lipid recovery. Almost no MFGM proteins could be noticed in the supernatant (Figure 3, lane 3), whereas whey proteins remained abundantly present. Upon the first washing, more than $80 \%$ of the mass of the original pellet was recovered in the washed pellet, as well as about $84 \%$ of the PL. Sugars, the main constituent of the pellet DM, were successfully removed by the washing step, together with some ash, proteins, and lipids. As such, DM recovery in the washed pellet was only $65 \%$ of the first pellet. This resulted in an increase in the PL content on DM of the pellet from 8.34 to $10.70 \%$, whereas $76 \%$ of the original whey PL were still recovered in the washed pellet. The SDS-PAGE of the first supernatant wash (Figure 3, lane 4) showed that only some residual whey proteins were washed out. After the second washing step, only $51 \%$ of the first pellet was recovered. This led to serious losses in lipids and PL. The PL DM was further increased to $11.18 \%$, but only $45.8 \%$ of the whey PL was recovered in the pellet after 2 washing steps. Presumably, the aggregates were broken down into smaller fragments, which remained in suspension. Compared with the first supernatant wash, the intensity of the spots on the SDS-PAGE gel increased, and MFGM proteins could clearly be distinguished in the second supernatant wash. Therefore, a second washing step does not seem advisable, because too many MFGM fragments were lost.

Table 5. Pellet recovery (mass \% of original whey total) after aggregation and washing of the pellet

\begin{tabular}{lccccccc}
\hline Pellet & Pellet mass & \multicolumn{1}{c}{ DM } & Ash & Protein & Sugars & Lipids & Polar lipids \\
\hline Original & $7.86 \pm 0.09$ & $20.1 \pm 0.4$ & $33.4 \pm 0.7$ & $44.5 \pm 1.6$ & $10.9 \pm 0.2$ & $97.7 \pm 3.2$ & $91.0 \pm 4.6$ \\
Wash 1 & $6.40 \pm 0.09$ & $13.1 \pm 0.5$ & $27.5 \pm 0.7$ & $37.8 \pm 1.6$ & $0.2 \pm 0.0$ & $92.2 \pm 3.5$ & $75.9 \pm 6.1$ \\
Wash 2 & $3.99 \pm 0.00$ & $7.5 \pm 0.1$ & $18.5 \pm 1.3$ & $22.6 \pm 0.6$ & Trace & $48.7 \pm 1.7$ & $45.8 \pm 3.2$ \\
\hline
\end{tabular}




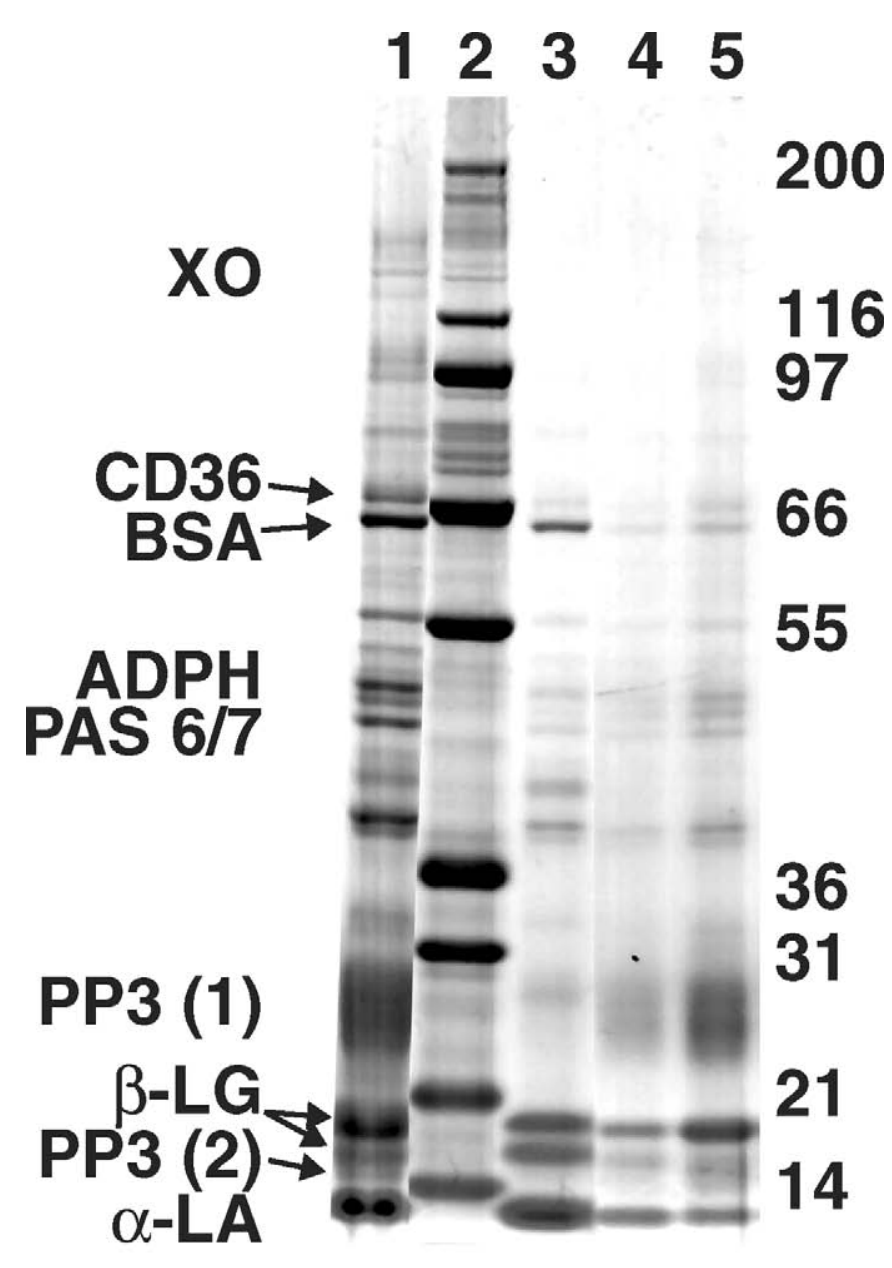

Figure 3. Sodium dodecyl sulfate-PAGE of acid buttermilk cheese whey supernatants after aggregation at optimal conditions $\left(55^{\circ} \mathrm{C}, \mathrm{pH}\right.$ 7.7 , and $0.205 \mathrm{~g}$ of $\mathrm{Ca} / 100 \mathrm{~g}$ of whey) and multiple washing steps. Lane 1: acid buttermilk whey; lane 2: molecular mass marker; lane 3: supernatant; lane 4: washing step 1 supernatant; lane 5: washing step 2 supernatant. Observed milk fat globule membrane (MFGM)proteins are xanthine oxidase (XO) adipophilin (ADPH), cluster of differentiation 36 (CD36), periodic acid Schiff 6/7 (PAS 6/7), and proteose peptone 3 fraction 1 and 2 (PP3). Observed whey proteins are BSA, $\alpha$-LA, and $\beta$-LG genetic variants $\mathrm{A}$ and $\mathrm{B}$.

\section{DISCUSSION}

The most significant parameter in MFGM aggregate formation was certainly the pH. Kanno and Kim (1990) found the isoelectric point of the whole MFGM fragment to be around 4.8. At this $\mathrm{pH}$, virtually all the Ca present in the whey is ionized. Upon increasing the $\mathrm{pH}$ above 4.8, the MFGM fragments will progressively be negatively charged. Similarly, the solubility of ionic Ca will significantly decrease (Fox and McSweeney, 1998), forcing $\mathrm{Ca}$ complexes to be formed. Because $\mathrm{Ca}$ is a bivalent ion, one ion can bind to 2 different MFGM particles. As such, upon a $\mathrm{pH}$ increase, an interaction between $\mathrm{Ca}$ and
MFGM fragments is favored, resulting in the formation of MFGM aggregates.

Upon a temperature increase, MFGM aggregation is increased, with a maximum at around $55^{\circ} \mathrm{C}$. The main reason for this is the decrease in Ca-ion solubility with an increase in temperature (Fox and McSweeney, 1998). However, MFGM proteins also can exert an influence on aggregation, because they are already reported to form disulfide stabilized complexes at temperatures around 55 to $60^{\circ} \mathrm{C}$ (Ye et al., 2002). As such, aggregate formation is further strengthened and the pellet becomes firmer. At temperatures beyond $60^{\circ} \mathrm{C}$, and especially at alkaline $\mathrm{pH}$, the intramolecular disulfide bonds of whey proteins such as $\alpha$-LA and $\beta$-LG begin to be reduced. The presence of $\mathrm{Ca}^{2+}$ can induce unfolding and even aggregation (Law and Leaver, 2000). This explains the increased protein recovery in the pellet at temperatures above $60^{\circ}$, at $\mathrm{pH}$ values above 7 (Figure $1 \mathrm{D}$ ), and at increased Ca concentrations. The fact that whey proteins at these $\mathrm{pH}$ and temperature take part in and interfere with the aggregation process could be the cause of the slight decrease in MFGM recovery in the pellet at temperatures above $60^{\circ} \mathrm{C}$ (Figure 1C).

In general, the effect of Ca addition on MFGM recovery was rather small. This result is somewhat in contrast with research done on whey clarification, in which $\mathrm{Ca}$ addition was found to be one of the most important factors (Pierre et al., 1992). Possibly, the fact that the acid buttermilk whey was already twice as rich in $\mathrm{Ca}$ as standard rennet whey masked the influence of further addition of $\mathrm{Ca}$.

\section{CONCLUSIONS}

A thermocalcic aggregation of MFGM particles followed by centrifugation was found to be a feasible process for MFGM fragment recovery, because after optimization of the experimental parameters, more than $90 \%$ of the whey PL were recovered in a small pellet. In particular, the $\mathrm{pH}$ was found to be a significant factor for aggregate formation. By SDS-PAGE, we found that in addition to MFGM fragments, whey proteins and the PP3 fraction (despite whether it is a true MFGM protein) were also involved in this aggregate formation. Further washing of the pellet to increase the MFGM content on a DM basis should be limited to one step, because otherwise the overall yield of these MFGM fragments becomes unacceptably low.

\section{ACKNOWLEDGMENTS}

B. Lewille and M. Jooris are acknowledged for their technical assistance. Büllinger Butterei (Büllingen, Belgium) is acknowledged for providing the acid buttermilk 
whey. Spectral Services (Köln, Germany) is acknowledged for providing the milk PL standard.

\section{REFERENCES}

Acker, L. 1969. Handbuch der Lebensmittel. Springer-Verlag, Berlin, Germany.

AOAC. 2002. Official Methods of Analysis. AOAC, Washington, DC.

Attebery, J. M., inventor. 1968. Removing lipid material from whey. US Pat. No. 3560219.

Basch, J. J., F. W. Douglas, L. G. Procino, V. H. Holsinger, and H. M. Farrell. 1985. Quantitation of CNs and whey proteins of processed milks and whey protein concentrates, application of gel electrophoresis and comparison with Harland Ashworth procedure. J. Dairy Sci. 68:23-31.

Best, E., B. Sprössler, and H. Plainer, inventors. 1982. Process for the removal of turbid material from whey. EP Pat. No. 0057273.

Boone, M., inventor. 2003. Quark from buttermilk and method for preparing and further processing. EP Pat. No. 1274314.

Bough, W. A., and D. R. Landes. 1976. Recovery and nutritional evaluation of proteinaceous solids separated from whey by coagulation with chitosan. J. Dairy Sci. 59:1874-1880.

Danthine, S., C. Blecker, M. Paquot, N. Innocente, and C. Deroanne. 2000. Progress in milk fat globule membrane research: A review. Lait 80:209-222.

De Wit, J. N., and R. De Boer, inventors. 1977. Method for the clarification of liquids containing whey protein. NL Pat. No. 7513645.

Ebeler, S. E., L. G. Phillips, and J. E. Kinsella. 1990. Purification of beta-lactoglobulin-Isolation of genetic-variants and influence of purification method on secondary structure. Milchwissenschaft 45:694-698.

Eckhardt, E. R. M., D. Q. H. Wang, J. M. Donovan, and M. C. Carey. 2002. Dietary sphingomyelin suppresses intestinal cholesterol absorption by decreasing thermodynamic activity of cholesterol monomers. Gastroenterology 122:948-956.

Fauquant, J., A. Pierre, and G. Brulé. 1985a. Clarification du lactosérum acide de caséinerie. La Technique Laitiere 1003:37-41.

Fauquant, J., E. Vieco, G. Brule, and J. L. Maubois. 1985b. Clarification of sweet cheese whey by thermocalcic aggregation of residual fat. Lait 65:1-20.

Fox, P. F., and P. L. H. McSweeney. 1998. Dairy Chemistry and Biochemistry. Blackie Academic \& Professional, London, UK.

Gésan, G., G. Daufin, U. Merin, J. P. Labbe, and A. Quemerais. 1995. Microfiltration performance-Physicochemical aspects of whey pretreatment. J. Dairy Res. 62:269-279.

Grasselli, M., L. E. Diaz, and O. Cascone. 1995. Whey clarification by a soluble polycationic agent. Biotechnol. Tech. 9:487-490.

Grindstaff, D. A., and W. P. Ahern, inventors. 1974. Process for pretreating raw cheese whey. US Pat. No. 3864506.

Hwang, D. C., and S. Damodaran. 1994. Selective precipitation of fat globule membranes of cheese whey by saponin and bile-salt. J. Agric. Food Chem. 42:1872-1878.

Hwang, D. C., and S. Damodaran. 1995. Selective precipitation and removal of lipids from cheese whey using chitosan. J. Agric. Food Chem. 43:33-37.

IDF. 1992. Milk and dried milk-Determination of calcium content. Flame atomic absorption spectrometric method. IDF Standard 154 International Dairy Federation, Brussels, Belgium.

IDF. 1993. Milk. Determination of nitrogen content. IDF Standard 20B. International Dairy Federation, Brussels, Belgium.

IDF. 2004. Whey cheese. Determination of dry matter. IDF Standard 58. International Dairy Federation, Brussels, Belgium.

IDF. 1986. Whey cheese. Determination of fat content. Röse-Gottliebgravimetric method. IDF Standard 59A. International Dairy Federation, Brussels, Belgium
Kanno, C. M., and D. H. Kim. 1990. A simple procedure for the preparation of bovine-milk fat globule-membrane and a comparison of its composition, enzymatic-activities, and electrophoretic properties with those prepared by other methods. Agric. Biol. Chem. 54:2845-2854.

Kanno, C., Y. Shimomura, and E. Takano. 1991. Physicochemical properties of milk-fat emulsions stabilized with bovine milk fat globule membrane. J. Food Sci. 56:1219-1223.

Law, A. J. R., and J. Leaver. 2000. Effect of $\mathrm{pH}$ on the thermal denaturation of whey proteins in milk. J. Agric. Food Chem. 48:672-679.

Lehmann, H., and I. Wasen, inventors. 1990. Method of dephospholipidating whey. US Pat. No. 4897279.

Mailliart, P., and B. Ribadeau-Dumas. 1988. Preparation of $\beta$-lactoglobulin and $\beta$-lactoglobulin-free proteins from whey retentate by $\mathrm{NaCl}$ salting out at low pH. J. Food Sci. 53:743-745.

Mather, I. H. 2000. A review and proposed nomenclature for major proteins of the milk-fat globule membrane. J. Dairy Sci. 83:203247.

Maubois, J. L., A. Pierre, J. Fauquant, and M. Piot. 1987. Industrial fractionation of main whey proteins. Bull. Int. Dairy Fed. 212:154-159.

Melachouris, N., inventor. 1977. Process for the recovery of whey protein having improved solution clarity using polyphosphates. US Pat. No. 4043990.

Nejjar, Y., D. Paquet, F. Aubert, and G. Linden. 1990. The PP3 component of the proteose-peptone-Extraction from unheated skim milk. Milchwissenschaft 45:84-87.

Noh, S. K., and S. I. Koo. 2004. Milk sphingomyelin is more effective than egg sphingomyelin in inhibiting intestinal absorption of cholesterol and fat in rats. J. Nutr. 134:2611-2616.

Pierre, A., Y. Legraet, J. Fauquant, M. Piot, C. Durier, and A. Kobilinsky. 1992. Optimization of physicochemical factors for whey clarification. Lait 72:405-420.

Roesch, R. R., A. Rincon, and M. Corredig. 2004. Emulsifying properties of fractions prepared from commercial buttermilk by microfiltration. J. Dairy Sci. 87:4080-4087.

Rombaut, R., J. V. Camp, and K. Dewettinck. 2005. Analysis of phospho- and sphingolipids in dairy products by a new HPLC method. J. Dairy Sci. 88:482-488.

Rombaut, R., J. Van Camp, and K. Dewettinck. 2007. Phospho- and sphingolipid content of selected dairy products as determined by high performance liquid chromatography coupled to an evaporative laser light scattering detector (HPLC-ELSD). J. Food Compos. Anal. 20:308-312.

Savant, V. D., and J. A. Torres. 2000. Chitosan-based coagulating agents for treatment of cheddar cheese whey. Biotechnol. Prog. 16:1091-1097.

Schmelz, E. M. 2004. Sphingolipids in the chemoprevention of colon cancer. Front. Biosci. 9:2632-2639.

Schmelz, E. M., D. L. Dillehay, S. K. Webb, A. Reiter, J. Adams, and A. H. Merrill. 1996. Sphingomyelin consumption suppresses aberrant colonic crypt foci and increases the proportion of adenomas versus adenocarcinomas in CF1 mice treated with 1,2-dimethylhydrazine: Implications for dietary sphingolipids and colon carcinogenesis. Cancer Res. 56:4936-4941.

Sorensen, E. S., L. K. Rasmussen, L. Moller, and T. E. Petersen. 1997. The localization and multimeric nature of component PP3 in bovine milk: Purification and characterization of PP3 from caprine and ovine milks. J. Dairy Sci. 80:3176-3181.

Spitsberg, V. L. 2005. Bovine milk fat globule membrane as a potential nutraceutical. J. Dairy Sci. 88:2289-2294.

Wu, A. C. M., W. A. Bough, M. R. Holmes, and B. E. Perkins. 1978 Influence of manufacturing variables on characteristics and effectiveness of chitosan products. 3. Coagulation of cheese whey solids. Biotechnol. Bioeng. 20:1957-1966.

Ye, A., H. Singh, M. W. Taylor, and S. Anema. 2002. Characterization of protein components of natural and heat-treated milk fat globule membranes. Int. Dairy J. 12:393-402. 